This is an informal report intended primarily for internal or limited external distribution. The opinions and conclusions stated are those of the author and may or may not be those of the laboratory.

\title{
UCID -16769
}

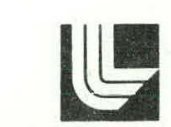

\section{I_AWRENCE I_IVERMORE LABORATORY}

University of California /Livermore, California

TOXIC VAPOR HAZARD OF HEATED MOCK HIGH EXPI.OSIVE

T. M. Distler

Y. M. Kwok

April 28, 1975

- NOTICE

This report was prepared as an account of work This repor by the United States Government. Nenergy sponsored by the United States nor the United States Eny of the United Development Administration, nor any of their employees, nor any of their, makes any subcontraciors, or their employes, assumes any legal warranty, express or implied, or assum, completeness liability or responsibility for the accuracy, complotuct or liability or responsiny information, apparatus, prould not or usefulness of any inforesents

process disclosed, or rep rights. 


\section{DISCLAIMER}

This report was prepared as an account of work sponsored by an agency of the United States Government. Neither the United States Government nor any agency Thereof, nor any of their employees, makes any warranty, express or implied, or assumes any legal liability or responsibility for the accuracy, completeness, or usefulness of any information, apparatus, product, or process disclosed, or represents that its use would not infringe privately owned rights. Reference herein to any specific commercial product, process, or service by trade name, trademark, manufacturer, or otherwise does not necessarily constitute or imply its endorsement, recommendation, or favoring by the United States Government or any agency thereof. The views and opinions of authors expressed herein do not necessarily state or reflect those of the United States Government or any agency thereof. 


\section{DISCLAIMER}

Portions of this document may be illegible in electronic image products. Images are produced from the best available original document. 


\section{ABSTR ACT}

Three types of mock high explosives, types 90503, LM-04, and RM-04-BF, were pyrolyzed in a temperature range between $200^{\circ}$ and $700^{\circ} \mathrm{C}$, and the gaseous products were then analyzed. Isocyanic acid, hydrogen cyanide, and cyanogen were found in the product gases.

\section{INTRODUCTION}

This study was prompted by concern about the safety of handling mock high explosive which has been subjected to degradation processes, especially pyrolysis. Three types of mock HE-90503, LM-04-0, and RM-04-BF - were chosen for a brief investigation of their thermal degradation products in a temperature range between $200^{\circ} \mathrm{C}$ and $700^{\circ} \mathrm{C}$.

The primary constituent $(60 \%$ to $70 \%)$ of these materials is cyanuric acid, $\mathrm{C}_{3} \mathrm{O}_{3} \mathrm{~N}_{3} \mathrm{H}_{3}$, which sublimes with decomposition to gaseous isocyanic acid, HNCO, at temperatures above $300^{\circ} \mathrm{C}$. The isocyanic acid readily condenses to a white polymer mixture at elevated temperatures, and more slowly at lower temperatures. The effccts of the remaining constituents, which may include barium nitrate, Viton, melamine, nitrocellulose, and tris ( $\beta$-chloroethyl) phosphate, do not seem to have been investigated.

\section{ELTERIMENTAL}

Initial experiments were carried out with $500 \mathrm{mg}$ of typc 90503 in a nitrogen atmosphere in a quartz tube furnace. Temperature increments of $100^{\circ} \mathrm{C}$ and $30-\mathrm{min}$ duration were used, with the gaseous products being swept out of the reaction zone by a slow stream of dry nitrogen and through a trap containing $10 \mathrm{ml}$ of $1 \underline{\mathrm{N}}$ aqueous sodium hydroxide.

At the end of each $30-\mathrm{min}$ period, the temperature was raised and the trap was analyzed for combined cyanide and cyanate using an argentometric titration with p-dimethylaminobenzalrhodanine as an end-point indicator. ${ }^{1}$ The results are shown in Fig. 1 plotted as the sum of all titratable products as a function of temperature. Although we determined that the condensed polymer entrained in the product gas stream does not interfere in this analytical technique, several questions remained unresolved. 1. Standard Methods for the Examination of Water, 12th ed. (American Public Health Assn., New York, 1965), p. 453. 


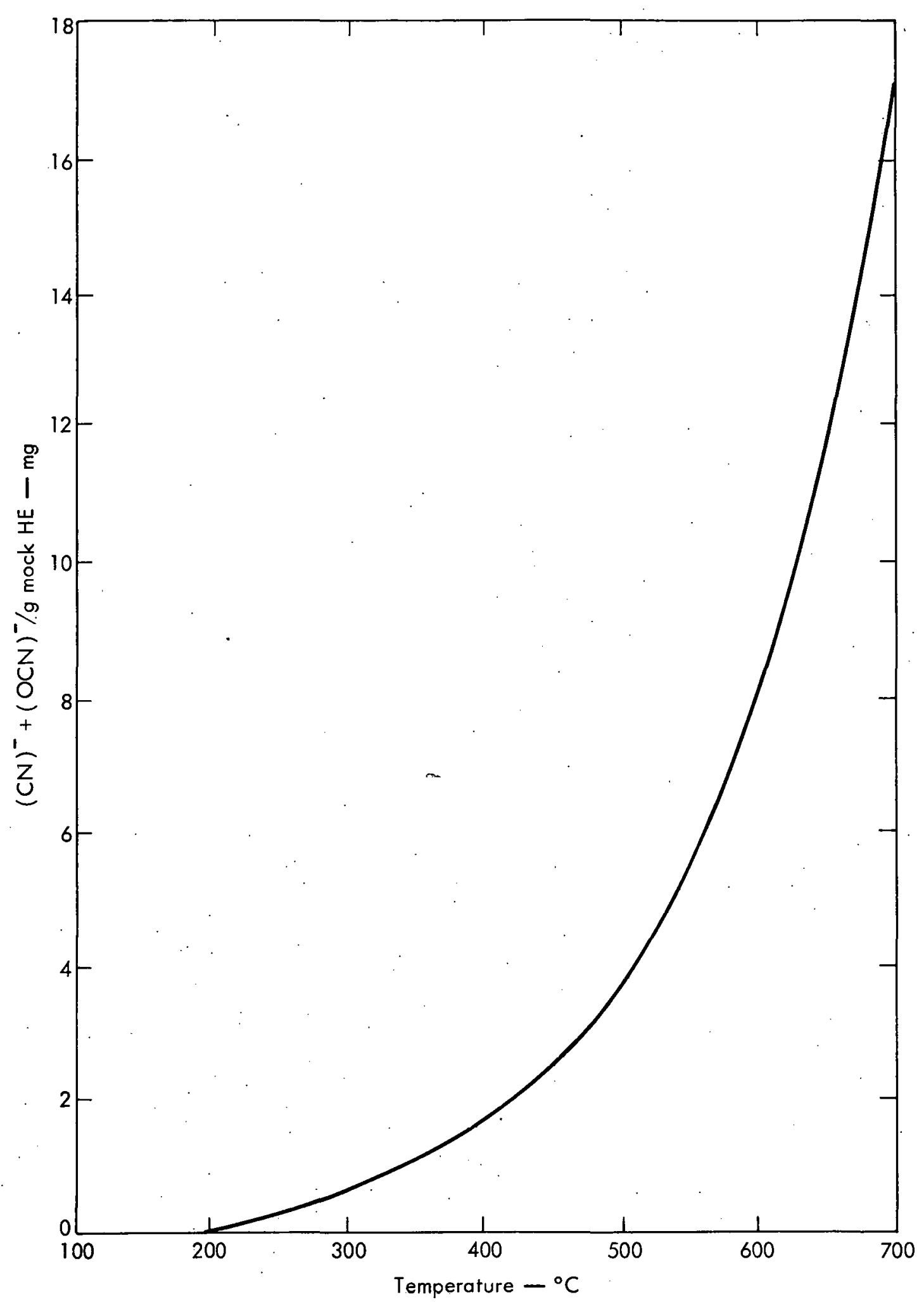

Fig. 1. Results of titration for type 90503 mock HE. 
First, if the gas contains appreciable quantities of cyanogen, the titration is probably underestimating the hazard; and second, if the gas contains a large proportion of unpolymerized isocyanic acid gas, the hazard may be somewhat overestimated because the material is continually removed by polymerization from the vapor phase over a period of time.

We used infrared analysis of direct gas samples to obtain qualitative answers to the above. An evacuated sampling bulb was inserted in the train to collect a portion of the gases evolved at $400^{\circ} \mathrm{C}$ with a slow stream of dry nitrogen. The gas was analyzed by IR absorption spectrophotometry. The IR spectrum taken in a 10-m cell on a Perkin Elmer Model 221 instrument indicated isocyanic acid as the principal species in the sample. Neither $\mathrm{HCN}$ or $\mathrm{C}_{2} \mathrm{~N}_{2}$ were found (see Fig. 2).

A second sample of the same pyrolysis gas similarly collected was stored for $40 \mathrm{hr}$ before IR analysis. No significant decrease in isocyanic acid vapor was noted. Thus polymerization does not appear to be an important process for reducing the vapor hazard once the material escapes the heated zone.

A further set of pyrolysis gas samples was collected at $650^{\circ} \mathrm{C}$, since it has been reported ${ }^{2}$ that isocyanic acid decomposes above $500^{\circ} \mathrm{C}$ to form $\mathrm{CO}_{2}, \mathrm{CO}, \mathrm{N}_{2}, \mathrm{HCN}$, $\mathrm{C}_{2} \mathrm{~N}_{2}$, and $\mathrm{H}_{2}$. The presence of HCN was confirmed using LM-04-0, and was inferred from absorptions centered at $3310 \mathrm{~cm}^{-1}$ and $2800 \mathrm{~cm}^{-1}$ (Fig. 3 ). A sample pyrolyzed at $750^{\circ} \mathrm{C}$ gave additional IR absorption peaks at 2550 and $2660 \mathrm{~cm}^{-1}$, which correspond to absorptions which have been reported for cyanogen. It may be safely assumed that all mock HE containing cyanuric acid can produce hydrogen cyanide and cyanogen at high temperature.

Very little can be said about the levels of $\mathrm{HCN}$ and $\mathrm{C}_{2} \mathrm{~N}_{2}$ likely to be found in the vicinity of thermally degraded mock $\mathrm{HE}$ since the reactions are complex, depending on time, temperature, and surfare conditions in the pyrolysis volume. It is conceivable, however, that several weight percent of the mock HE could be converted to hydrogen cyanide.

We treated the remaining two types of mock HE in the same way as the initial $500 \mathrm{mg}$ of type 90503, collecting the evolved gases in $1 \mathrm{~N} \mathrm{NaOH}$, and titrating. The integral curves are shown in Figs. 4 and 5, each point representing the total isocyanic acid evolved up to that temperature.

The curves generally show isocyanic acid evolution increasing roughly exponentially with temperature, except for type RM-04-BF which shows a markedly lower yield and temperature dependence. This is probably due to oxidation of the sample during pyrolysis by the barium nitrate which is not a component of 90503 or LM-04-0.

\section{SUMM ARY AND CONCLUSIONS}

Three types of mock HE - 90503, RM-04-BF, and LM-04-0 - were thermally degraded in a tcmpcrature range between $200^{\circ} \mathrm{C}$, and $700^{\circ} \mathrm{C}$, and the evolved vapors 2. R. A. Back and J. Childs, Can. J. Chem. 46, 527 (1968). 


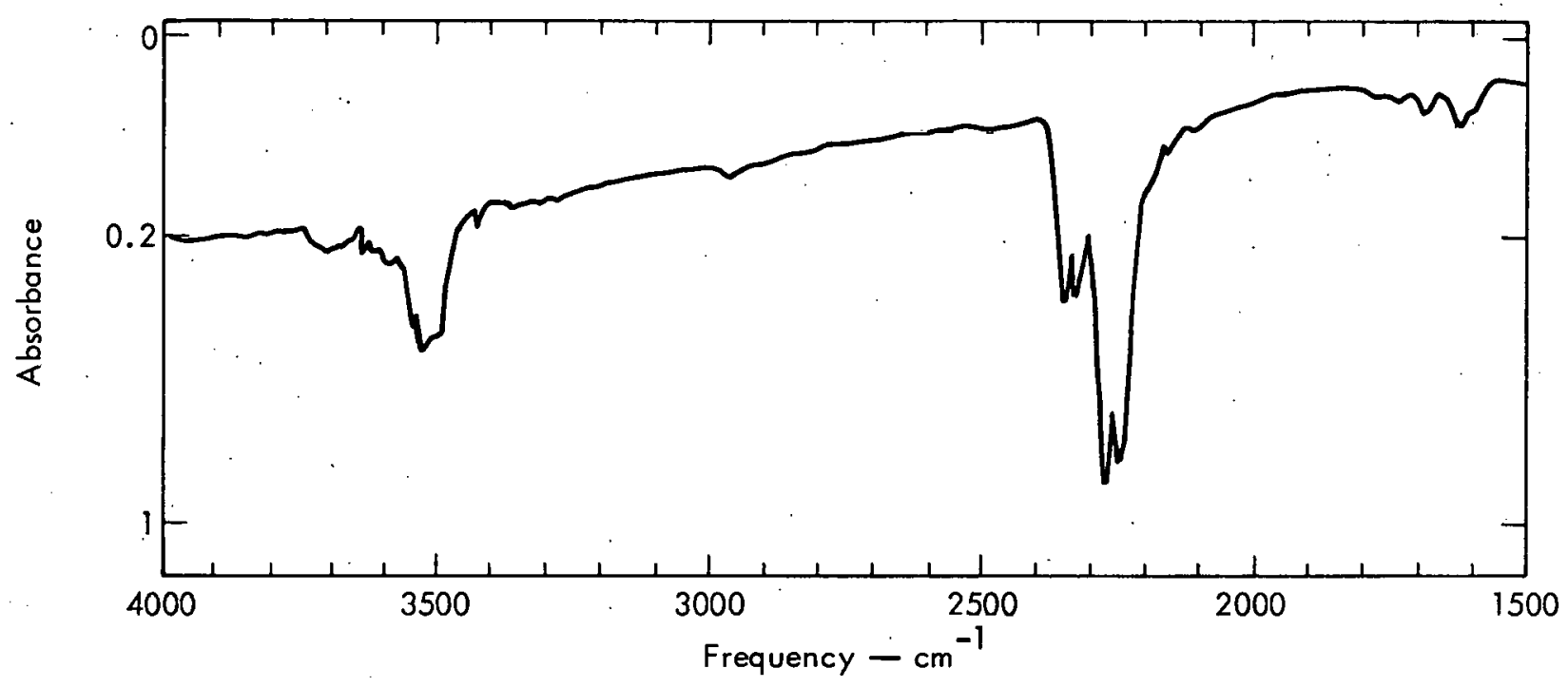

Fig. 2. IR absorption spectrum of $400^{\circ} \mathrm{C}$ pyrolysis gas. 


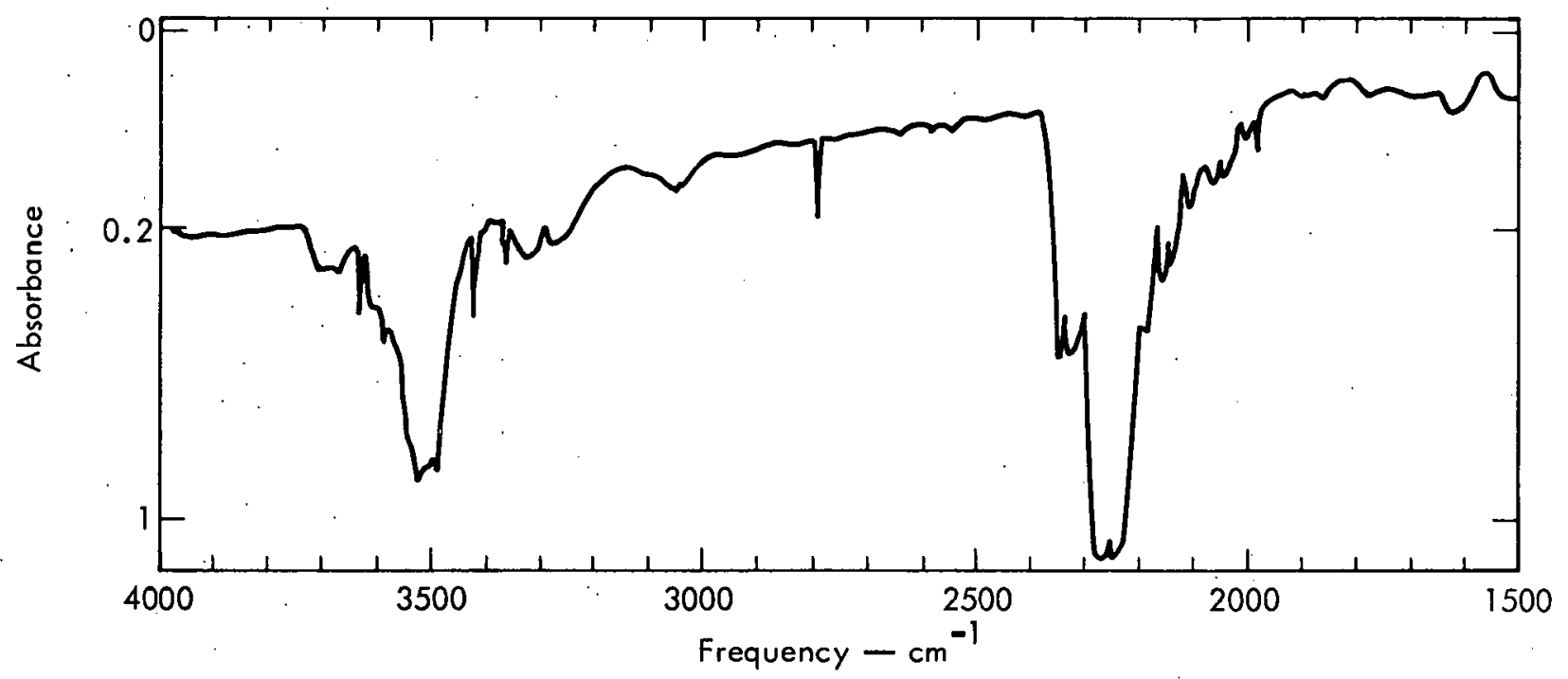

Fig. 3. IR absorption spectrum of $650^{\circ} \mathrm{C}$ pyrolysis gas. 


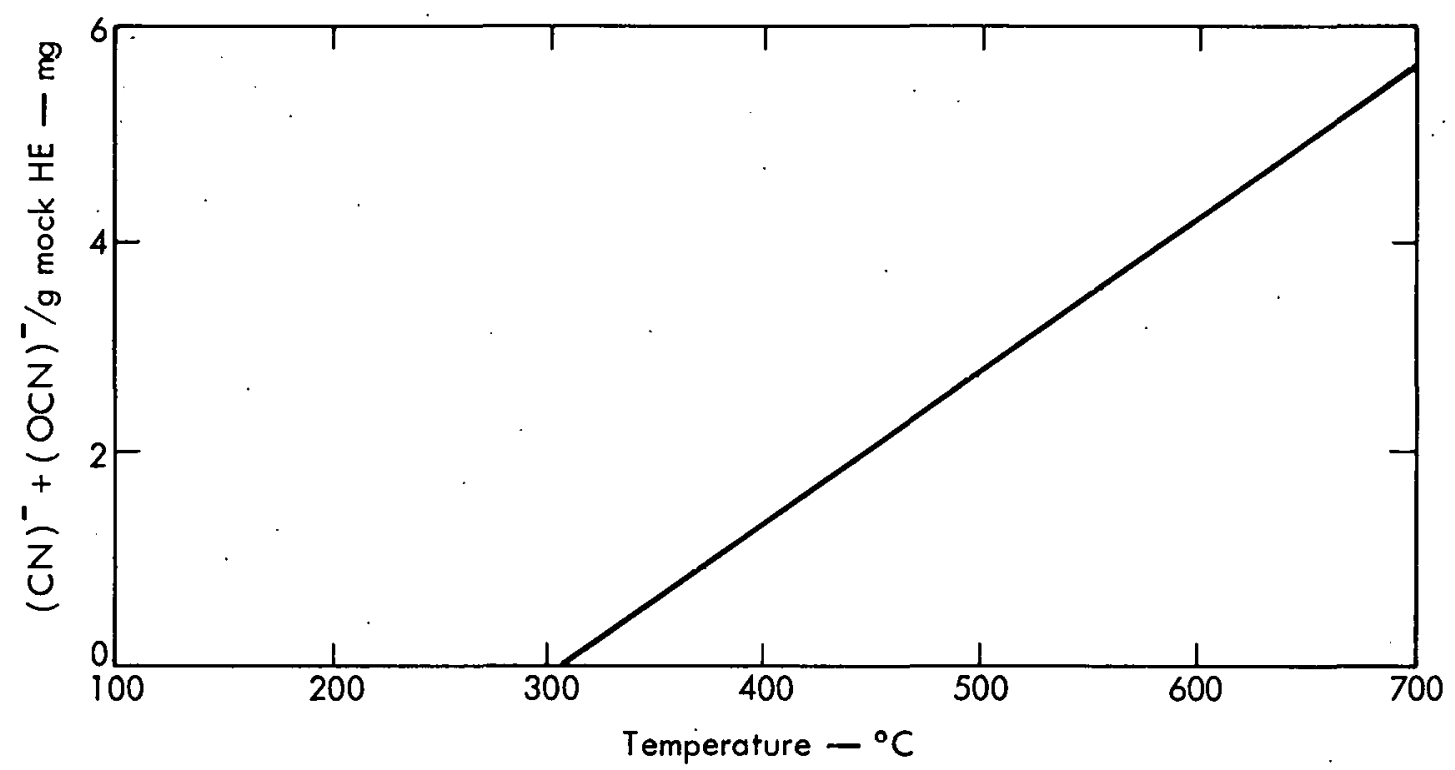

Fig. 4. Results of titration for type RM-04-BF mock HE. 


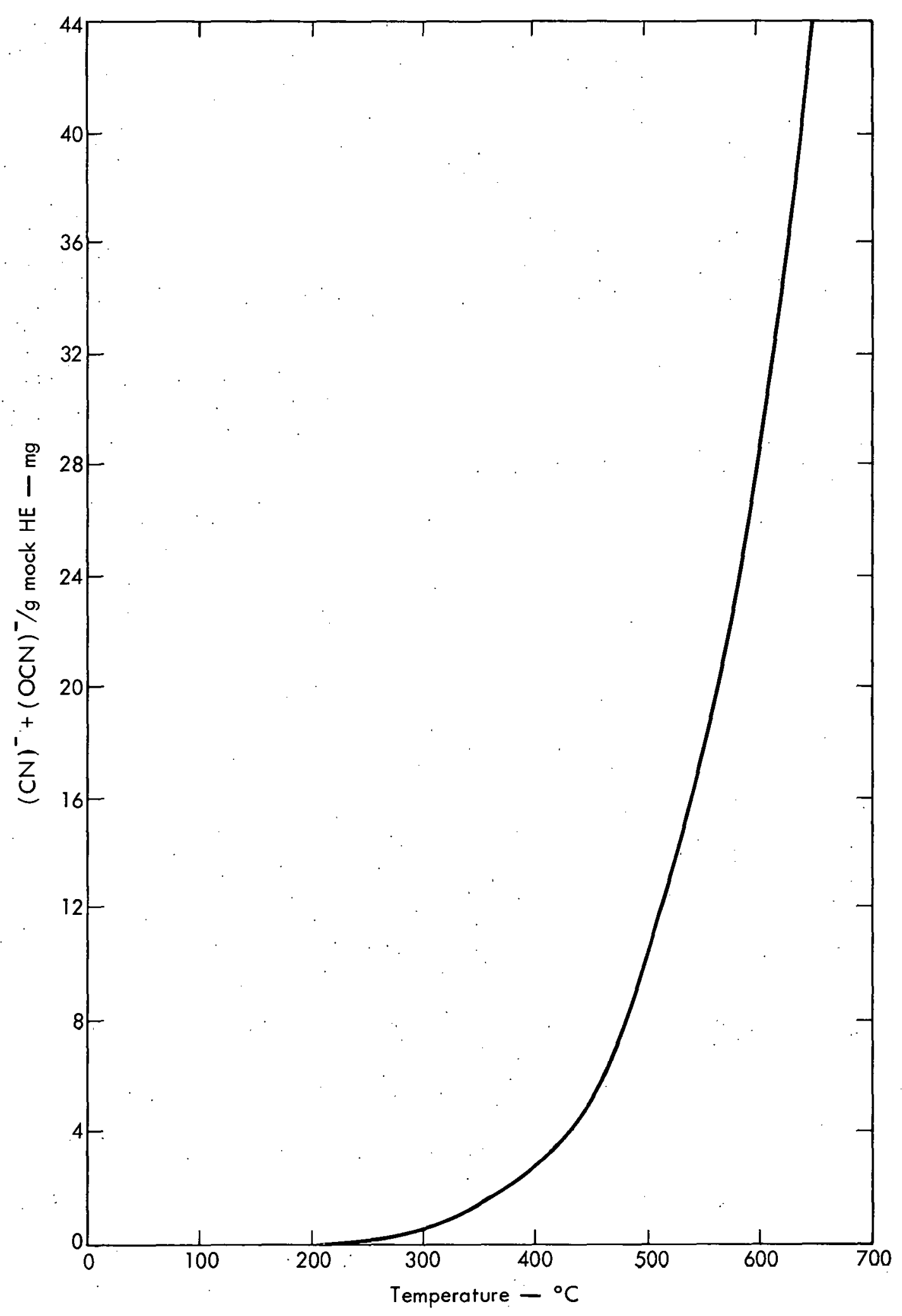

Fig. 5. Results of titration for type LM-04-0 mock HE. 
analyzed. The decomposition of these types of mock HE is determined largely by their cyanuric acid content and can be divided into two stages. In the first stage, beginning just below $300^{\circ} \mathrm{C}$, the cyanuric acid vaporizes with decomposition to toxic isocyanic acid gas. At about $500^{\circ} \mathrm{C}$, the decomposition of the evolved isocyanic acid marks the onset of stage 2. The products of this pyrolysis are $\mathrm{CO}_{2}, \mathrm{CO}, \mathrm{N}_{2}, \mathrm{HCN}, \mathrm{H}_{2}$, and some $\mathrm{C}_{2} \mathrm{~N}_{2}$.

In stage 1 pyrolyses between $300^{\circ} \mathrm{C}$ and $500^{\circ} \mathrm{C}$, hazardous quantities of isocyanic acid are likely to result. In addition, a white powdery condensate will probably be encountered which may also represent an inhalation hazard. The quantity of isocyanic acid found will depend on the conditions during and after the pyrolysis: temperature, time at temperature, temperature gradients, and presence of moisture which increases the rate of polymerization.

In stage 2 pyrolyses $\left(500^{\circ} \mathrm{C}\right.$ and above), hydrogen cyanide, cyanogen and carbon monoxide may be encountered together with the isocyanic acid. Experiments have shown poor reproducibility in yields of hydrogen cyanide and cyanogen, but do show a correlation with pyrolysis time and surface area. For long times at temperatures of $600^{\circ} \mathrm{C}$, hydrogen cyanide yields of several percent by weight of mock HE appear feasible.

While no experiments were done in air, it is expected that a flow of air will have several effects on the pyrolysis. More isocyanic acid will result; dilution by air and transport from the heated zone should reduce losses due to polymerization. At higher temperatures, $\mathrm{HCN}$ and $\mathrm{C}_{2} \mathrm{~N}_{2}$ production should be decreased because of the shorter residence times in the pyrolysis zone and the oxidizing atmosphere.

Figures on the toxicity of isocyanic acid do not appear to be available, although some inferences may be drawn from the relative toxicities of cyanides and cyanates. Sodium and potassium cyanides are more toxic than the corresponding cyanates by a factor of about 50. This would imply a maximum allowable concentration of isocyanic acid in air of several hundred ppm, although the acrid odor and lachrymatory properties of the free acid probably will make the practical limit much lower.

\section{ACKNOWLEDGMENT}

The authors gratefully acknowledge the assistance of $P$. L. Barry in the fabrication and operation of the pyrolysis apparatus.

$\mathrm{VRM} / \mathrm{bl}$ 
NOTICE

"This report was prepared as an account of work sponsored by the United States Government. Neither the United States nor the United States Energy Research \& Development Aduiuistration, nor any of their employees, nor any of their contractors, subcontractors, or their employees, makes any warranty, express or implied, or assumes any legal warranty, express or implied, or assumes any legal
liability or responsibility for the accuracy, completeness or usefulness of any information, apparatus, product or process disclosed, or represents that its use would not infringe privately-owned rights."

Printed in the United States of America Available from

National Technical Information Service

U.S. Department of Commerce 5285 Port Royal. Road

Springfield, Virginia 22151

Price: Printed Copy $\$$ *; Microfiche $\$ 2.25$

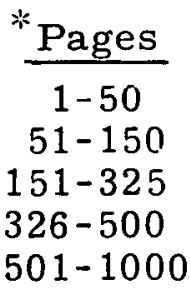

NTIS

Selling Price

$\$ 4.00$

$\$ 5.45$

$\$ 7.60$

$\$ 10.60$

$\$ 13.60$ 